\title{
English in Hong Kong: Emergence and Decline
}

\author{
John E. Joseph \\ Department of Applied Linguistics, The University of Edinburgh, 14 Buccleuch \\ Place, Edinburgh EH8 9LN
}

The current situation of English in Hong Kong is the subject of two competing discourses, a public one centred on the decline of language standards, and an academic one centred on the emergence of a distinctive Hong Kong English. It is not the case that one is right and the other wrong; they are two ways of looking at the same linguistic development, and both have validity for their very different purposes. After considering the social changes behind the 'decline' account, this paper examines the grounds for recognising an emerging Hong Kong English. It then looks at how various political changes might affect a future Hong Kong identity, such that Hong Kong English might eventually become a public reality as well as an academic one.

\section{Introduction}

Hong Kong in the 1990s is a fascinating linguistic crucible, as the wide range of papers in this issue reflects. The situation provides linguists with a wealth of material to study, yet at the same time challenges our conceptual and methodological presuppositions. When I arrived in 1993 to take up the Chair of English Language and Linguistics at the University of Hong Kong, I assumed that certain categories of linguistic and sociolinguistic analysis were universally applicable, and that if we merely applied them widely and diligently enough we could get a reasonable understanding of the linguistic situation here. By the time of my departure at the end of 1996, I had come to appreciate more fully the uniqueness of the historical situation. I had learned, in the light of this uniqueness, that some of the analytic categories I had taken to be universally applicable are in fact contingent upon a certain set of historical factors being in place which we do not find here.

Examples include concepts like diglossia or triglossia, together with the categories of formal and informal language that operate within them. These seem to work very well in helping us understand sociolinguistic situations in many places around the globe, but when it comes to Hong Kong, any attempt to dichotomise in the way these categories do appears hopelessly oversimplified, and ends up obfuscating rather than clarifying the linguistic situation for us. Some other analytical artefacts do seem to transfer to the Hong Kong situation, though now I am inclined always to wonder whether other situations have existed or will exist in which they fail to apply entirely, and whether situations in which they have so far appeared to apply ought not to be re-examined in the light of the Hong Kong experience.

As Professor of English, I found myself in the middle of a very interesting gulf between, on the one hand, a public discourse about English in Hong Kong founded upon the metaphor of a decline, and on the other hand, a linguistic 
discourse in the academy which not only rejects the substance of that public discourse but denies the validity of its foundational metaphor. What I hope to show in this paper is that these two seemingly opposed discourses are in fact two sides of the same coin, and that each is quite predictable from a historical perspective that takes account of the ideologies underlying them. I shall also venture some predictions from that historical perspective, with the proviso that they are no more certain than anything else about the future of Hong Kong, again in view of the uniqueness of the present circumstances.

\section{The 'Myth' of Declining English}

How the public discourse about English in Hong Kong has developed over the years is the subject of a study in progress by Angel Lin. The general perception is certainly that sometime in the last couple of decades this discourse has become centred upon the notion of a deterioration in English standards. Commissions have been set up to study this problem, generously funded bodies have been established to address it. Most of the linguists who have worked in Hong Kong in recent times, and we are very numerous, have come here directly or indirectly as a result of this concern. Some of us have echoed the perception of a decline in English standards, particularly when participating in a public forum, where to do otherwise would be perceived (rightly or wrongly) as being out-of-touch with reality and abrogating professional responsibility. However, in professional discourse, it is rare for linguists to speak in terms of declining English standards. Instead, the view tends to be that the perception of linguistic deterioration is a false, or at least a skewed, perception.

The notion of linguistic decline depends upon a concept of 'good' and 'bad' in language which linguistics has rejected as 'prescriptive' since the nineteenth century. In a forthcoming book I argue that this rejection has been merely superficial (Joseph forthcoming), and that the activity and discourse of 'descriptive' linguistics is ultimately inseparable from that of 'prescriptivism'. Be that as it may, this distinction is crucial to the ideology under which most linguists operate. To say that a language situation is deteriorating implies that it is going from better to worse, an implication which linguists are trained early on not to entertain. Further complicating the case of Hong Kong, the 'good' situation of the past is one in which not only all university students, but all people in jobs which put them in contact with the public were (or are imagined to have been) perfectly bilingual and literate in Chinese and English, the colonial language. Western expatriate linguists need to guard against seeming to suggest that a change from colonial-plus-native-language bilingualism to native-language monolingualism is bad. Quite apart from the fact that Hong Kong cannot reasonably be said to be moving toward monolingualism (as will be shown below), such a suggestion could be taken to mean not that bilingualism and literacy are good and monolingualism and illiteracy are less good, which many of us do think, but rather that English is good and Chinese is bad, a proposition which I think any linguist would reject immediately as nonsensical, since we have no independent criteria by which to measure the quality of languages, even relative to one another.

For these same reasons it seems to many linguists in Hong Kong that the idea 
Table 11993 Survey of languages spoken and understood by whole population of Hong Kong

\begin{tabular}{|l|c|c|c|}
\hline Language & Understand & Speak & $\begin{array}{c}\text { Speak - 1983 } \\
\text { Survey }\end{array}$ \\
\hline Cantonese & $91.5 \%$ & $91.9 \%$ & $98.5 \%$ \\
\hline English & $68.6 \%$ & $65.8 \%$ & $43.3 \%$ \\
\hline Putonghua (Mandarin) & $61.9 \%$ & $55.6 \%$ & $31.9 \%$ \\
\hline Chinese & $7.3 \%$ & $6.6 \%$ & not in survey \\
\hline Hakka & $7.4 \%$ & $6.0 \%$ & $7.5 \%$ \\
\hline Chiu Chau & $7.0 \%$ & $5.2 \%$ & $9.3 \%$ \\
\hline Fukien & $4.2 \%$ & $4.1 \%$ & $4.2 \%$ \\
\hline Sze Yap & $3.2 \%$ & $3.3 \%$ & $6.3 \%$ \\
\hline Shanghainese & $3.7 \%$ & $2.7 \%$ & $4.1 \%$ \\
\hline Cantonese dialects & $3.5 \%$ & $2.5 \%$ & $4.7 \%$ \\
\hline Other Chinese dialects & $1.5 \%$ & $1.5 \%$ & not in survey \\
\hline Other European languages & $1.9 \%$ & $1.8 \%$ & not in survey \\
\hline Others & $0.4 \%$ & $0.3 \%$ & $3.6 \%$ \\
\hline
\end{tabular}

(Adapted from Bacon-Shone \& Bolton, forthcoming: 26)

of a decline in standards of English is logically untenable. But more than that, it is directly contradicted by empirical research. Table 1, cited from a Hong Kong language survey project by Bacon-Shone and Bolton (forthcoming), shows the number of English speakers in Hong Kong increasing by 50\% between 1983 and 1993.

Bacon-Shone and Bolton have found a steadily accelerating rise from the 1930s to the present in both the proportion and the sheer numbers of Hong Kong people proficient in English, certainly giving the lie to any statement to the effect that 'Hong Kong is a monolingual (Cantonese-speaking) and ethnically homogeneous (98\% Chinese) society' (So, 1987: 249), or even this slightly tempered version: 'Hong Kong is essentially a monolingual Cantonese-speaking society where English is used in only a restricted number of domains' (So, 1992: 79).

The data do raise certain problems, starting with how to reconcile them with government statistics indicating that Filipinos, most of them employed as domestic helpers, formed more than $1 \%$ of the 1993 population, and presumably all spoke and understood home languages that would have to be classed as 'other' in the table. Nevertheless, the figures follow the same patterns reported by T'sou (this volume). Another potential problem is that the data are from self-reporting rather than 'objective' observation, but that is the only way in which comparison could be made across the six-decade time span, since all the pre-1983 data are from self-reporting to census takers. Moreover, for the issues of language and identity that are currently bound up with language use in Hong Kong and that will be explored later in this paper, people's subjective impressions of their own 
Table 2 Responses to the question: 'How well do you know English?'

\begin{tabular}{|l|c|c|}
\hline & 1983 & 1993 \\
\hline 'Quite well' /'Well' /'Very well' & $5.1 \%$ & $33.7 \%$ \\
\hline 'Not at all' /'Only a few sentences' /'A little' & $92.8 \%$ & $66.3 \%$ \\
\hline
\end{tabular}

(Adapted from Bacon-Shone \& Bolton, forthcoming: 27)

language abilities matter at least as much as any external assessment. BaconShone \& Bolton's study also shows a marked increase between 1983 and 1993 in the proportion of people claiming to know English with considerable proficiency (Table 2).

How is it possible, then, that a perception 180 degrees removed from the empirical linguistic 'reality' of Hong Kong as shown by these figures could have become all but universal in the territory, linguists aside? Is it a sort of mass hallucination, not far removed from mass hysteria? Although linguists here would never say so directly, I think that something along those lines is implied by the argument that English is actually on an upward course, and its decline is a myth. The problem with the word 'myth' is that, as it is generally used, it implies the existence of a single 'real' (perhaps Platonic) reality to which the person who uses the word has access, while those accused of harbouring the myth do not, and are therefore deluded. Before attacking this problem, let us consider a plausible socio-historical explanation for how the 'myth' of deteriorating English standards in Hong Kong could have come about.

In 1993 the University of Hong Kong was the older of two universities in the territory. Today there are six, with a seventh on the way. The number of university student places has tripled in less than three years. At the same time, the number of those going abroad for university education, mainly to UK and North America, has increased enormously along with the colony's affluence since the late 1980s. Families who can afford it send their children overseas, which means that the University of Hong Kong gets the cream of the poorer families. Twenty or thirty years ago this was not so. The well-off went to the very British University of Hong Kong, while middle-class students might get a place in the Chinese University if they were lucky. But as recently as the early 1970 s, only $2 \%$ of secondary school graduates in Hong Kong went on to university. Today the figure is closer to $20 \%$. Consider for a moment that next $18 \%$ of top graduates from 1972, who today would be going on to university. Where did they go back then? To jobs as clerks and secretaries, in which they dealt extensively with the public. There were no executive management jobs open to them; the executive sector, like the economy, was much smaller and dominated by expatriates. So when you visited a government or business office downtown, the people who served you at the window may well have been from the top $5 \%$ of their graduating class, highly educated and with excellent English. Today, with $20 \%$ of the graduates going to university and from there to executive management jobs in a still burgeoning sector, the people who serve you at the window downtown may not even have come from the top quarter of their graduating 
class. In that sense, there has been a decline in standards, but as part of a great increase in educational opportunity, which most of us consider a very good thing.

In other words, when people talk about a decline in English standards in Hong Kong, they are reacting in part to a social change. This point was already made by Lord (1987):

In Hong Kong, over the past two decades, English has changed from being a purely colonial language whose use was largely restricted to government circles, the law, high-level business, and a few other sectors, to becoming an indispensable language of wider communication, for a growingly large range of people, all the way down from top brass to clerks, from taipans to secretaries ... Not unnaturally, it has seemed to many that standards of English are falling. (Lord, 1987: 11; italics in the original)

By italicising the word 'seemed', Lord does his part to portray the discourse of decline as mythical. Again, this is not entirely wrong. It is not as though some entity called the English language exists in Hong Kong and used to be better but now is worse. Whatever we mean when we talk about 'English' - whether we have in mind a set of words and rules existing independently from speakers, a form of knowledge in the minds or brains of speakers, or a way of behaving in communicative discourse - it is clear that what is happening in Hong Kong is that more people are getting access to English, not fewer. As is typical when a privilege of the few becomes open to the 'hoi polloi', it is no longer perceived as having the same quality as before.

From this point of view the 'myth' of declining English in Hong Kong is a type of linguistic snobbery. That does help explain one aspect of my experience here: the fact that, without exception, the people who have complained to me in vociferous and emotional terms about the decline of English in Hong Kong have been ethnically Chinese. Westerners sometimes mention it, but with a resigned shrug. Ethnically Chinese Hong Kong people who themselves are highly proficient in English get very worked up, insisting that this is an urgent issue, a crisis situation that must be got under control. Then they inevitably add that not only is the university students' English terrible, but their Chinese is just as bad - an interesting point which I explore further in Joseph (1997). Actually I do not think that they say these things entirely out of snobbery, and shall elaborate further on about what else I suspect is behind it. But it is the case that in discoursing this way, they establish the value of the kind of English they and other university graduates of their generation possess, and that is increasingly rare among today's students.

The first thing they would deny is that what they speak is something that ought to be identified as 'Hong Kong English'. Only linguists ever contemplate the notion of such an entity; other people scoff at it. Yet it is almost certainly the case that the perception of a decline in English standards is tied in part to the emergence of a syntactically distinctive Hong Kong English with clear interlanguage features. In Joseph (1987), a study of language standardisation worldwide beginning with the question of how and when 'new' languages get recognised, I maintained that three sets of factors need to be taken into account: linguistic form, function, and status. Form and function were already recognised by Kloss (1952) 
in his early work on standardisation. As for status, it is essentially a political matter, and stands at the intersection of linguistics with sociology and psychology, as well as political science. The following sections consider Hong Kong English in the light of these three criteria, beginning with form.

\section{The Formal Distinctiveness of Hong Kong English}

As Kloss noted, the first requirement for a new language to be recognised is simply that it differ in form (in his terms, Abstand) from the already recognised variety. This is clearly the case for Hong Kong English. One marker of Hong Kong English that regularly occurs in discourse samples is the lack of the Standard English distinction between Count Noun Phrase and Mass Noun Phrase. In this respect the simple Noun Phrase (NP) in Hong Kong English is structurally Chinese, as shown in Figure 1, where CNP stands for 'common noun phrase', CL for 'classifier', CL-P for 'classifier phrase', and $X$ for 'to be determined'.
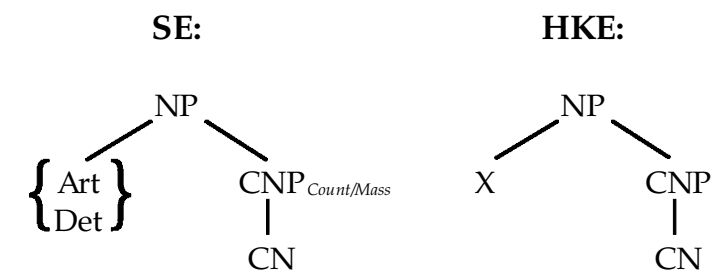

HKE:

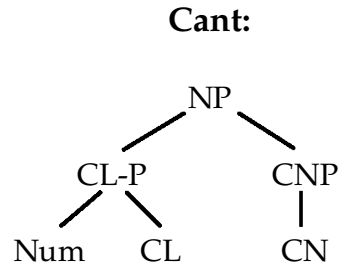

Figure 1 Structure of simple NP in Standard English (SE), Hong Kong English (HKE) and Cantonese (Cant.)

For any sociolinguists who instinctively recoil at the sight of a syntactic tree, they are really nothing to be frightened of. They are simply to help us visualise how words in a sentence are related to one another, and have no significance in and of themselves. Last year the 20 non-Western students on my MA course on Grammar, Discourse and Meaning - mostly English teachers, and some of the best local university English graduates of the last two decades - were astonished to learn that noodle is a count noun rather than a mass noun in Standard English, and that one does not say ${ }^{*} a$ bowl of noodle in parallel with a bowl of rice. As shown in Figure 2, the nouns faahn 'rice' and mihn 'noodles' take the same nominal classifier in Cantonese, wún 'bowl'.

\begin{tabular}{|c|c|c|c|c|c|}
\hline SE: & $\begin{array}{l}\text { a. a bowl of rice } \\
a^{\prime} \text {. *a bowl of rices }\end{array}$ & HKE: & $\begin{array}{l}\text { a. a bowl of rice } \\
a^{\prime} .{ }^{*} \text { a bowl of rices }\end{array}$ & Cant.: & $\begin{array}{l}\text { a. yāt wún faahn } \\
\text { (one bowl rice) }\end{array}$ \\
\hline & $\begin{array}{l}\text { b. *a bowl of noodle } \\
b^{\prime} \text {. a bowl of noodles }\end{array}$ & & $\begin{array}{l}\text { b. a bowl of noodle } \\
b^{\prime} \text {. }{ }^{*} \text { a bowl of noodles }\end{array}$ & & $\begin{array}{l}\text { b. yât wún mihn } \\
\text { (one bowl noodle) }\end{array}$ \\
\hline
\end{tabular}

Figure 2 
a. SE

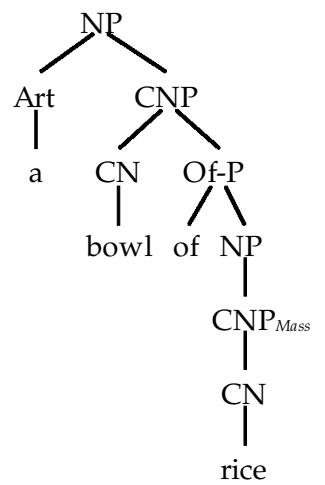

rice b. SE

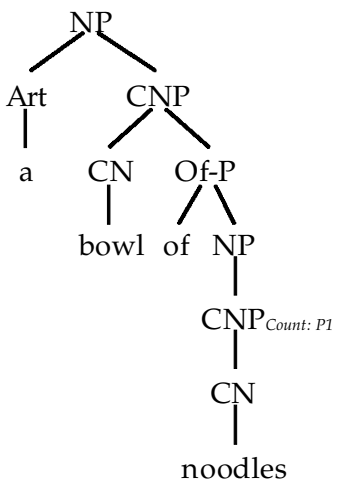

d. HKE Continuum
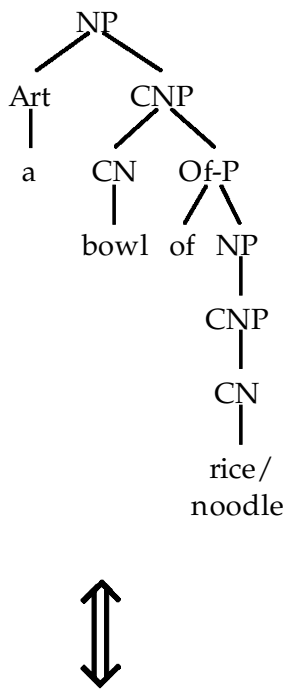

c. Cant.

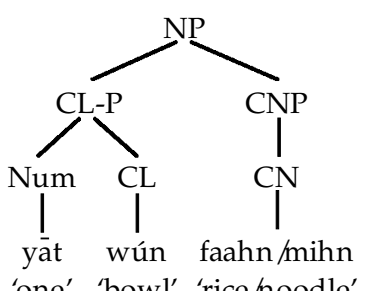

'one' 'bowl' 'rice/noodle'

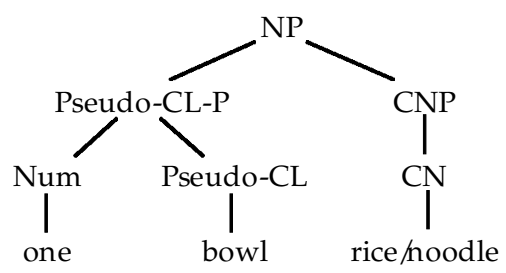

\section{Figure 3}

In Chinese, every common noun selects a particular classifier, so that in Cantonese 'a book' is yāt bún syù, 'a university' is yát gàan daaih-hohk, and so on. Chinese learners of English implicitly expect that if two nouns select the same classifier in Chinese, their English equivalents will show identical syntactic behaviour. They are befuddled when this is not so. A bowl of noodles sounds just as strange to my highly proficient MA students as does " $a$ bowl of rices to them or me.

In Figure 3, the syntax of these noun phrases is shown in, on the left, Standard English and Cantonese, and on the right, Hong Kong English represented as an interlanguage continuum.

For Standard English in (a) and (b) I am following the notation of Baker (1995), which is useful for this kind of work because it does not commit one to any particular theory of syntax. The NP consists of an Article, $a$, and a CNP, whose head is the common noun $(\mathrm{CN})$ bowl. This CNP selects a phrase headed by the 
preposition of as its complement. The complement of that phrase is another CNP which will always be specified as Count or Mass. If it is a Count CNP, then it will be further specified as singular or plural, whereas the Mass CNP does not have this specification.

Looking now to (c), we find that the Cantonese equivalent of these two NPs is a single structure, consisting of a CL-P and a CNP. The CL-P consists of the number yat and the head, the classifier (CL) wún. The CNP is headed by a noun for which there is no evidence to suggest that it is syntactically marked as Count or Mass. Chinese has no direct singular or plural marking of nouns or verbs. Demonstratives show interesting number phenomena, but here too there is no real evidence of a count-mass distinction in Cantonese. The other main difference between the English and Cantonese phrases is that in English rice and noodles are not the head of the highest CNP, whereas in Cantonese faahn and mihn are. English structures like a lot of rice seem to show something closer to the Chinese structure, with a lot of behaving like a compound quantifier and rice like a head noun; but that is not actually crucial to the analysis at hand.

For Hong Kong English in (d), at the top end we have virtually the Standard English structure, at the bottom virtually the Chinese one. This is not to say that Hong Kong English lacks a singular-plural distinction; that distinction exists and functions as a marker of where individual speakers lie on the continuum of interlanguage variation. But in the Standard English noun phrase, singular-plural is a secondary distinction, applying only when count rather than mass has been selected. Even speakers at the top end of the Hong Kong English continuum have little or no sense of the count-mass noun distinction, even if they have a well-developed proficiency with singular and plural markers. Instead, as I have noted, there is a strong implicit sense for these speakers that nouns selecting the same classifier in Chinese should show the same syntactic behaviour in English. That is the main reason for my labelling bowl here as a pseudo-classifier. My suspicion, subject to further investigation, is that the presence of what we might term a 'pseudo-classifier effect' even at the SE end of Hong Kong English is responsible for the non-standard subject-verb agreement one finds even in those highly proficient speakers.

There are two points to all this. The first is that Hong Kong people are not simply making random errors in English. Rather, people are making the same 'errors' (from the point of view of Standard English) in regularly recurring patterns, many of them traceable to the influence of Cantonese. Given this regularity of structure, it makes sense from a linguist's point of view to speak of Hong Kong English as an emerging 'language'. The second point is that the 'emergence of Hong Kong English' and the 'decline of English standards in Hong Kong' are one and the same thing, looked at from two different points of view. In some ways two opposite points of view, because 'emergence' implies that English is in the process of becoming a language of Hong Kong (using 'of' in the strong sense of 'belonging to'), whereas 'decline' implies that Hong Kong is losing English. There is in fact a sense in which Hong Kong is losing English, and it can be expressed precisely thus: the British or American or other foreign standard of correct English has ceased to be the majority norm for Hong Kong. Probably more 
people here than ever before speak 'correct' British English, yet as a proportion of the English-speaking population, they have never been smaller.

This development was probably inevitable once universal education, all or largely in English, was instituted in the territory in the late 1970s. Given the massivenumbers of students involved, there would have been no way to prevent the development from ensuing that is simultaneously the emergence of Hong Kong English and the decline in English standards. If it seems paradoxical that the spread of education should be connected with a decline in standards, this association is made routinely in the contexts of North American, British and Western European education. People there have come slowly and painfully to realise that, given inequalities in the home environments from which students come and the limitations on human and economic resources which societies can deploy toward education, choices have to be made between being bound to traditional academic standards and educating the masses. No one has yet shown how to achieve both, and few are ready to call for abandoning the masses for the sake of the standards.

\section{The Status of Hong Kong English}

In the context of English in Hong Kong, if history teaches us anything it is that the 'decline' in externally-imposed standards must occur if English is to survive in post-colonial Hong Kong (see Harris, 1989). New 'internal' standards must replace them - and that is precisely what has been happening with the emergence of a distinctive form of English. Again, Hong Kong people are not making random errors in English, but regularly occurring patterns largely traceable to the influence of their other principal language. It was by just such a process that the Romance languages cameinto being, an emergence that was at the same time a crumbling of the standards of Latin measured against the external criterion of Virgil and Cicero, and not a random crumbling, but one connected to the other languages spoken in the former Roman Empire. In the middle ages, the Romance dialects were already taking on their distinctive forms, but it was only over the course of many centuries that they came to be recognised as distinct 'languages' (see Wright, 1982). Particularly where writing was concerned, but also in prestigious spoken registers, there was good Latin, conforming to classical standards, and bad Latin, where those standards were giving way to the influences of the vernacular language. With the Renaissance and the spread of the modern idea of nationhood, the status of this 'bad Latin' changed and people began to think of it as something else, their language. In the case of France, by the eighteenth century it became an idée fixe that French was the most rational of all human languages, an opinion which continues even now to be widely held in French culture.

The status of Hong Kong English today is somewhat comparable to that of 'bad Latin' in the later middle ages, though there is a twist. The typical pattern in the recognition of a new language or form of a language is that a group of partisans within the native population begin asserting linguistic autonomy, and there ensues a struggle for international recognition. In the case of Hong Kong English, international recognition has come in the almost total absence of local assertion. Hong Kong English is, for example, one of the forms of English under study in the massive International Corpus of English (ICE) project, initiated by the late Sidney Greenbaum. The lack of any positive recognition of Hong Kong 
English in the local public discourse is perhaps not surprising, given that the emergence of other Englishes, including American, Australian, Canadian, Indian, New Zealand, and Singapore English, as well as Quebec French, Venezuelan Spanish, Brazilian Portuguese and the like, have always been post-colonial phenomena in the most literal sense (for fine studies of the post-colonial emergence of new Englishes in Singapore and Malaysia, see Platt \& Weber, 1980; in Sri Lanka, Parakrama, 1995; and for an overview, Platt et al., 1984). In some cases the emergence took a few years, in others entire decades, after the withdrawal of the colonial power. We do not find cases of local varieties of a language attaining official or social recognition as distinct 'languages' during the time of colonial rule. So it may be that the best we can expect is that Hong Kong English will be a future development. That is, although in terms of linguistic form it is well along the path of emergence, in terms of status we could not, projecting from historical evidence, reasonably expect it to attain recognition until after 1997, other than from linguists focusing on its formal distinctiveness.

This is not to say that initial steps toward the creation of that status are not discernible. The very fact that university students in Hong Kong are by and large oblivious to any sense that their English is 'bad' can be seen as an early stage in the development of language status for Hong Kong English. These people have, after all, been studying English since the age of four or five, and if they have got to university, especially the University of Hong Kong, they have probably always been the best at English among their peers. They are quite befuddled, sometimes even amused, to arrive at university and encounter expatriate and foreigneducated teachers telling them that the English they have been consistently praised for is deficient. One does not see them heading in panic to the English Centre to 'improve' their English, unless they are specifically ordered to do so. Again, these are signs that a 'local' standard is in operation, even if that standard has as yet no recognition or status within the local discourse about English.

If the emergence of a formally distinctive English in Hong Kong, also known as the decline in English standards, was inevitable once universal education was instituted in 1978, then the eventual recognition of this 'new English' and the accordance to it of the status of 'Hong Kong English' within the public discourse as well as within the specialised discourse of linguists, if it comes to pass after 1997, will appear in the perfect vision of hindsight to have been inevitable once the end of British colonial rule in Hong Kong was decided upon in 1984. Again, history leads us to expect that Hong Kong English will not be publicly recognised until after 1997, and that its attainment of public status will be closely connected with its use in particular linguistic functions, to be discussed in the next section. This is the real wild card, because the distribution of languages in official and non-official functions in post-1997 Hong Kong depends crucially on future policies of the Beijing and Hong Kong governments, and on the development of a Hong Kong identity, all of which are far from predictable.

\section{The Functions of Hong Kong English}

While the attainment of language status depends upon the use of a language in certain functional spheres (what Kloss calls its Ausbau), it is also the case that use in those spheres depends on a certain status having already been attained. 
Status and function are intertwined in a dialectical fashion. The account in Joseph (1987) says or at least implies that language status begins with a group of native-speaking partisans who, having learned standard-language functions in the colonial language, then begin using the new language in those functions, sometimes increasing the formal differences in the process. By this means the new status spreads to the population at large and ultimately gains national and international recognition.

Again, this is what has been observed regularly in post-colonial situations, as well as in the emergence of standard European languages in the Renaissance and after. But Hong Kong is not exactly moving into a post-colonial situation, at least not the typical one where a colony is granted independence. Rather it is being turned over to another power, the People's Republic of China, which did not exist until more than one hundred years after Hong Kong became a British colony. The PRC has its own standard spoken language, Putonghua, and written language, for which it uses simplified characters rather than the traditional ones still in use in Hong Kong. The majority first language of Hong Kong, Cantonese, does serve in some spoken standard-language functions in the PRC - though at this point the discussion becomes extremely complex, because in those functions a special form of Cantonese is used which is itself in a diglossic relationship with 'colloquial' Cantonese dialects.

With colloquial Cantonese, standard spoken Cantonese, formal spoken Cantonese, spoken and formal Putonghua, written Chinese in traditional and simplified characters, and a distinctive written Cantonese already available, what functions could possibly be left for Hong Kong English to fill after 1997? It will remain a co-official language, and so long as the territory remains part of the common law tradition, English will not be far distant from legal usage and status even when proceedings are superficially in Chinese. In addition, there is a widespread feeling in Hong Kong that English is the language of international business and tourism, as well of science, and that there will therefore remain economic and educational imperatives for learning and using it. And from a different sort of 'functional' perspective, there is the fact that language mixture, or code-switching, is so widely attested in ostensibly Cantonese discourse in Hong Kong that the borders between the languages are becoming ever more nebulous, despite the great structural gap between them. But again, even that gap is narrowing, based on what we saw for Hong Kong English in Figure 3, and arguably in the other direction too, as discussed in Joseph (1997).

First, however, there is a further set of possibilities for the functional development of Hong Kong English. One of the fastest growing and most interesting interfaces of late between linguistics and sociology, and psychology as well, has been the study of language and identity (as just a small sample of relevant work, see Belay, 1996; Edwards, 1985; Fitzgerald, 1993; Gergen, 1989; and for an early study in the Hong Kong context, Bolton \& Kwok, 1990). Not just national identity, but identities of all sorts, including local ones, sexual ones, generational ones, and purely individual ones (see Gergen, 1991; Young, 1996). Each of us possesses a barrage of identities which we have taken on or have constructed for ourselves, and which are manifested in part through language. For people in Hong Kong today, identity is very much an issue. The most salient 
aspect of it for now is that Hong Kong is losing its 'official' British identity. That identity has been little more than official for the last thirty years, since Britain adopted a hands-off cultural policy subsequent to the anti-colonial uprisings of the late 1960s. As Turner (1995) makes clear, the identity replacing it is not a Chinese one. This is not obvious to the casual observer: Hong Kong identity is nebulous, and the binding role of Chinese ethnicity within it is one of the most striking aspects to the outsider. Yet Hong Kong identity began to go its own way from mainland Chinese identity during the Cultural Revolution in the early to mid 1970s. Some drift back toward Chinese identity took place after the announcement of the handover in 1984, but stopped dramatically and definitively after the Tiananmen Square massacre in 1989. Hong Kong identity is also very distinct from Taiwanese identity, though they do have features in common that neither shares with the mainland identity.

How the uniqueness of Hong Kong identity manifests itself in linguistic terms is complex and still developing. Predictably, 'local' people surveyed do not indicate a sense of their personal identity being bound up with English, except in tiny numbers. The historical momentum is toward Chinese linguistic identity, bound up not only with Cantonese but with Putonghua, even in spite of the nervousness caused by Tiananmen Square and more recent events suggesting that Beijing may make little pretence of abiding by the Joint Declaration and the Basic Law. At the moment, linguistic identity in Hong Kong is still conceived essentially in terms of English versus Chinese (despite Yau's (1992: 16) belief that this 'old antagonism ... is now out of date'). But after July 1, 1997, it is not impossible, and indeed seems rather likely, that the focus of the local politics of identity will be to establish the distinctiveness of Hong Kong people within greater China. Linguistically, the use of Cantonese in official functions in Hong Kong will go some distance toward manifesting that distinctiveness; but it simultaneously presents the possibility of a regional Hong Kong-Guangdong identity emerging. If Beijing continues to see the major threat to national stability as residing in movements for regional autonomy, it would not be surprising if active efforts were made to promote the use of Putonghua over Cantonese in Hong Kong. In 1997, when Cantonese is the first language to more than $90 \%$ of the population here, it may seem unthinkable that the language could ever be weakened. But in fact the figures cited in Table 1 suggest otherwise. Most Hong Kong people are bilingual or trilingual, and that is the first stage in the demise of a language. There are plenty of historical cases of large populations largely or entirely losing their language in favour of another one within a relatively short span of time - one has only to think for example of a place like Wales, where this occurred when education, communications and opportunity for travel were only a fraction of what they are now. The point is that if the Beijing government wanted to, and went about it in the right way, they could significantly increase the spread of Putonghua in Hong Kong at the expense of Cantonese (again despite the protestations of Yau, 1992). The people of Hong Kong might equally well find their primary identity within the common language of China.

But if Hong Kong people were to strengthen and intensify their non-mainland identity - that is, regardless of any question of their loyalty to the Beijing government, if they were to want to manifest their historical and cultural 
differences vis-à-vis the rest of China rather than what they share, and particularly if Cantonese were to undergo suppression of the sort discussed above, then they might in a sense 'remember' that the majority of them also know English. That memory of English, even if it does not take the form of everyone in Hong Kong being fluent in the language - i.e. if it is only a memory of having known English, as is sometimes the case with ethnic languages and identities in the US - could form a part of Hong Kong linguistic identity, for those people who wanted to assert it. Insofar as the history of other peoples is a guide, it is when this identity function emerged, and only then, that one could expect a recognition of 'Hong Kong English' to become a part of the public (non-linguistic) discourse. This possibility is further bolstered by the ongoing emergence of a 'global' identity in postmodern culture, in which English plays the predominant linguistic role.

\section{Conclusion}

The changing patterns in the use of English in Hong Kong can best be understood within a historical perspective which takes account of similar developments in other times and places while remaining aware that the particular circumstances of Hong Kong in the 1990s are unique. The perception of a decline in English standards, which dominates the public discourse, and that of the emergence of Hong Kong English, which dominates the specialised discourse of linguists, are actually two sides of the same coin, two ways of looking at the same phenomenon.

Linguists risk having only a very partial understanding of the linguistic situation if we dismiss the popular perception outright because it is contradicted by our 'scientific' data. We would do better to think in terms of 'stories': linguists have a different story concerning language in Hong Kong than the one that has emerged in public discourse. Both matter in respects so different to one another that it makes little sense to compare them; but in any case surely the last thing we want to say is that the story in public discourse does not matter. It matters very much indeed. It is through such stories that a society constitutes and maintains itself, determines the direction in which it will develop, creates an identity and, when necessary, a resistance.

What people are reacting to as a decline in English standards in Hong Kong is, at one level, a tremendous rise in social opportunity that has produced a democratisation of the language, allowing a distinctive Hong Kong English to emerge, as such Englishes have already emerged in Singapore, India, and various other places around the globe. The idea of such a language is not one which Hong Kong people take seriously - not yet, anyway. But the cultural identity crisis could deepen in the months and years ahead if Beijing plays the cultural unity and stability card too strongly and suppresses the vibrant written Cantonese literature, mainly in the form of comic books and popular newspapers which the mainland government undoubtedly considers vulgar and subversive. Then the possibility that Hong Kong English might find its functional niche and become a locus of cultural identity and expression no longer seems far-fetched at all.

\section{Acknowledgement}

I am grateful to Kingsley Bolton, Godfrey Harrison, and Elaine Y. L. Ho for helpful comments on an earlier draft of this paper, and to fellow colloquium 
participants, particularly Phil Benson, Samuel Leung and Sue Wright, for useful information and thoughtful advice. I alone am responsible for any errors of fact or interpretation.

\section{References}

Bacon-Shone, J. and Bolton, K. (forthcoming) Charting multilingualism: Language censuses and language surveys in Hong Kong. In M.C. Pennington (ed.) Language in Hong Kong at Century's End. Hong Kong: University of Hong Kong Press.

Baker, C.L. (1995) English Syntax. (2nd edn) Cambridge, MA: MIT Press.

Belay, G. (1996) The (re)construction and negotiation of cultural identities in the age of globalization. In H.B. Mokros (ed.) Interaction and Identity. New Brunswick, NJ and London: Transaction Publishers, Rutgers University.

Bolton, K. and Kwok, H. (1990) The dynamics of the Hong Kong accent: Social identity and sociolinguistic description. Journal of Asian Pacific Communication 1, 147-72.

Edwards, J. (1985) Language, Society and Identity. Oxford and New York: Basil Blackwell, in association with André Deutsch.

Fitzgerald, T.K. (1993) Metaphors of Identity: A Culture-Communication Dialogue. Albany: State University of New York Press.

Gergen, K.J. (1989) Warranting voice and the elaboration of the self. In J. Shotter and K.J. Gergen (eds) Texts of Identity. London: Sage.

Gergen, K.J. (1991) The Saturated Self: Dilemmas of Identity in Contemporary Life. Basic Books, Harper Collins.

Harris, R. (1989) The worst English in the world? Inaugural lecture from the Chair of English, The University of Hong Kong. Supplement to the Gazette, April 1989, 36 (1), 37-46.

Joseph, J.E. (1987) Eloquence and Power: The Rise of Language Standards and Standard Languages. London: Pinter; New York: Blackwell.

Joseph, J.E. (1997) The Tao of identity in heteroglossic Hong Kong. Forthcoming in International Journal of the Sociology of Language (special issue on Islands and Identity in Sociolinguistics, Tope Omoniyi (ed.).

Joseph, J.E. (forthcoming) The Correctness of Words: Plato's Cratylus in Historical and Theoretical Perspective. Amsterdam and Philadelphia: John Benjamins.

Kloss, H. (1952) Die Entwicklung neuer germanischer Kultursprachen von 1800 bis 1950. München: Pohl \& Co. (2nd edn, Düsseldorf: Schwann, 1978).

Lord, R. (1987) Language policy and planning in Hong Kong: Past, present, and (especially) future. In R. Lord and H.N.L. Cheung (eds) Language Education in Hong Kong. Hong Kong: The Chinese University Press.

Parakrama, A. (1995) De-Hegemonizing Language Standards: Learning from (Post) Colonial Englishes about 'English'. London and New York: Macmillan.

Platt, J. and Weber, H. (1980) English in Singapore and Malaysia: Status, Features, Functions. Oxford: Oxford University Press.

Platt, J., Weber, H., and Ho Mian Lian (1984) The New Englishes. London: Routledge.

So, D.W.C. (1987) Searching for a bilingual exit. In R. Lord and H.N.L. Cheung (eds) Language Education in Hong Kong. Hong Kong: Chinese University Press.

So, D.W.C (1992) Language-based bifurcation of secondary schools in Hong Kong: Past, present and future. In K.K. Luke (ed.) Into the Twenty First \{sic\} Century: Issues of Language in Education in Hong Kong. Hong Kong: Linguistic Society of Hong Kong.

Turner, M. (1995) 60's/90's: Dissolving the people. In M. Turner and I. Ngan (eds) Hong Kong Sixties: Designing Identity. Hong Kong: Hong Kong Arts Centre.

Wright, R. (1982) Late Latin and Early Romance. Liverpool: Francis Cairns.

Yau Shun Chiu (1992) Language policies in post-1997 Hong Kong. In K.K. Luke (ed.) Into the Twenty First \{sic\} Century: Issues of Language in Education in Hong Kong. Hong Kong: Linguistic Society of Hong Kong.

Young, Y.K. (1996) Identity development: From cultural to intercultural. In H.B. Mokros (ed.) Interaction and Identity. New Brunswick, NJ and London: Transaction Publishers, Rutgers University. 